\title{
The Effects of Leg Muscle Strength Exercises on Students' Front Kick Abilities in Pencak Silat Extracurricular Activities at KH. Ahmad Dahlan Islamic Boarding School Teluk Kuantan
}

\author{
T Rodica $^{1^{*}}$, E Nurmai $^{1}$ \\ ${ }^{1}$ Faculty of Sports Science, Universitas Negeri Padang, Prof. Dr. Hamka Street, Padang, Indonesia \\ *Corresponding author. Email: tryrodika@gmail.com
}

\begin{abstract}
The research problem was the lack of Students' Front Kick Abilities in Pencak Silat Extracurricular Activities at KH.Ahmad Dahlan Islamic Boarding School in Teluk Kuantan. The purpose of this study was to determine the effect of Leg Muscle Strength Training on Students' Front Kick Abilities in Pencak Silat Extracurricular Activities at KH.Ahmad Dahlan Islamic Boarding School in Teluk Kuantan. The type of this research is an experiment. The population in this study were all male students who participated in the pencak silat extracurricular activities at the KH. Ahmad Dahlan Islamic Boarding School, Teluk Kuantan, amounting to 12 people. The sample in the study used total sampling technique so that the sample in this study were 12 people. The research instrument used a test measuring the ability of the front kick. Data analysis and hypothesis testing used comparative analysis techniques by using different mean test formula ( $\mathrm{t}$ test) with a significant level of 0.05 . From the data analysis carried out the following conclusions are obtained: There is a significant effect between strength training and the ability of students' front kicks in the extracurricular activities of pencak silat at Islamic boarding school KH.Ahmad Dahlan Teluk Kuantan. With To> Tho (2,30> $2,13)$.
\end{abstract}

Keywords: Leg muscle, front kick abilities, pencak silat

\section{INTRODUCTION}

Indonesia is a developing country and actively carries out development in the fields of economy, social, politics and educational by the government with the people which aims to create a just and prosperous Indonesian society based on the Pancasila and the 1945 Constitution. Development in the field of education is a struggle to educate the life of the nation, in improving the quality of life of Indonesian people physically, spiritually and socially in realizing an advanced, just and prosperous society as explained in the 2005 Sports Law in Chapter 1 Article 1 point 11 explaines that "educational of sports is physical education and sports carried out as part of a regular and continuous education process to obtain knowledge, personality, skills, health and physical fitness".

Considering the importance of the role of sport in human life, also in an effort to participate in advancing quality Indonesian people, the Indonesian government conducts coaching and development in the field of sports, such as holding sports competitions which are usually followed by sportsmen. Pencak silat is one of the sport competitions event holding nationally or even international matches.

All of basic movements of pencak silat, especially kicking techniques are divided into several kicks, namely crescent kicks, front kicks and $\mathrm{T}$ kicks. Specifically, the front kick, the leg muscle strength is very important to get the maximum kick.

The leg muscles strength is very important to get the maximum kick. Leg muscle strength is related to the strength and speed of dynamic leg muscle contractions and involves the removal of the maximum leg muscles in the fastest time. Basic techniques in pencak silat are the subjects that must be mastered by each student. Without mastering basic techniques, the results of punches or kicks will not be good. The basic techniques in pencak silat are: sawhorse, stance, strokes, kicks and stance. One of the basic techniques that must be mastered in the sport of pencak silat is the front kick technique. Kick is the attack of the legs and feet which consists of a sweep of a knee and cutouts. Generally, kick attacks are widely used in pencak silat sports, especially on the front kick, can be interpreted as a front kick that can hit the point over the opponent due 
to the position of the kick in front of the opponent. A good front kick requires a lot of very important techniques in order to stay on target. With a good kick, you can easily steal points from your opponent. To achieve the basic techniques of good and strong kicks need to be implemented through a regular training program, especially in the leg muscles, to achieve maximum results. Regular training must be supported by a quality training program, directed and has exercise guidelines so that the exercise achieves a maximum results such as squat jump exercises, up and down stairs, jump boxes, and sprint running exercises. Leg muscle strength training requires a good physical condition. With this leg muscle strength training, the students will be better, more accurate, and stronger in doing front kicks.

Based on observations made at KH. Ahmad Dahlan Islamic boarding school in Teluk Kuantan, there were students who took part in the Pencak Silat Extracurricular activities. The writer found that many students did not do the basic techniques pencak silat well, especially front kick techniques andthey did wrong kicking techniques with lack of muscle strengthof lack in kicking, lack of speed in making kicks so they can be easily anticipated, and lack of training time for physical conditions for students / athletes.

Based on the description above, the writer was interested in conducting research entitled: The Effect of Leg Muscle Strength Exercises on Students' Front Kick Abilities in Pencak Silat Extracurricular Activities at KH.Ahmad Dahlan Islamic Boarding School in Teluk Kuantan.

\section{METHOD}

The research method used in this research was experimental treatment. The research with an experimental approach is to find a relationship between the consequences of two intentional interfere factors generated by covering or reducing or eliminating other factors. This research took place at Islamic Boarding School KH. Ahmad Dahlan, Teluk Kuantan. The research was carried out during the Pencak Silat extracurricular activities at KH.Ahmad Dahlan Islamic Boarding School in Teluk Kuantan. The population of this study was all male students who participated in the pencak silat extracurricular activities at the Pondok Pesantren KH. Ahmad Dahlan, Teluk Kuantan, totaling 12 people. The sampling technique in this study was total sampling. So, the sample in this study was 12 male students who participated in the Pencak Silat Extracurricular activities at KH.Ahmad Dahlan Islamic Boarding School in Teluk Kuantan. The instrument of the study used a front kick ability test. Data analysis carried out in this study is significant test " $t$ ". It is to find out the significant level of difference between variable $\mathrm{X}$ (leg muscle strength training) and $\mathrm{Y}$ variable (kicking sandsack) that is the effect of leg muscle strength on students' front kick ability in pencak silat extracurricular activities at Islamic Boarding School KH. Ahmad Dahlan Teluk Kuantan.

\section{RESULTS AND DISCUSSION}

\section{Data Description}

Based on the problems in the previous section described, the variables in this study are the effect of training on the ability of students to kick in the pencak silat extracurricular activities of $\mathrm{KH}$ Ahmad Dahlan Islamic Boarding School in Teluk Kuantan. Final test and graph image of frequency distribution bar chart results of the pre test and post test.

\begin{tabular}{|c|c|c|c|}
\hline \multicolumn{4}{|c|}{$\begin{array}{l}\text { Data on Student's First Kick Ability Test Results } \\
\text { Pencak Silat Extracurricular at KH.Ahmad Dahlan } \\
\text { Islamic Boarding School Teluk Kuantan. } \\
\text { Table 1. The preliminary test data of distribution of } \\
\text { frequency on the ability of students' front kicks in } \\
\text { extracurricular pencak silat Islamic boarding school } \\
\text { KH. Ahmad Dahlan Teluk Kuantan. }\end{array}$} \\
\hline No. & Interval & Frequency & Percentage $\%$ \\
\hline 1 & $14-15.32$ & 3 & $25 \%$ \\
\hline 2 & $\begin{array}{c}15.33- \\
16.65\end{array}$ & 3 & $25 \%$ \\
\hline 3 & $\begin{array}{c}16.66- \\
17.89\end{array}$ & 4 & $33.33 \%$ \\
\hline 4 & $\begin{array}{l}17.90- \\
19.22\end{array}$ & 1 & $8.30 \%$ \\
\hline \multirow[t]{2}{*}{5} & $\begin{array}{l}19.23- \\
20.55\end{array}$ & 1 & $8.30 \%$ \\
\hline & Amount & 12 & $100 \%$ \\
\hline
\end{tabular}

Based on the preliminary test data on the ability of students' front kicks in the extracurricular activities of the Pencak Silat Islamic boarding school of KH Ahmad Dahlan Teluk Kuantan, from 12 samples studied with a frequency of 3 students a score of $14-15.32$ or $25 \%$ with a frequency of 3 students with a score of 15.3316.65 or $25 \%$, a frequency of 4 students with a score of $16.66-17.89$ or $33.33 \%$, a frequency of 1 student, a score of $17.90-19.22$ or $8.3 \%$, a frequency of 1 student, a score of $19.23-20.55$ or $8.3 \%$.

3.1.2 Data of Final test on ability of students in Pencak Silat Extracurricular at KH. Ahmad Dahlan Islamic Boarding School Teluk Kuantan.

Based on the preliminary test data of the Student's Front Kick in the Pencak Silat Extracurricular Activities of KH. Ahmad Dahlan Islamic Boarding School, Teluk Kuantan, from 12 samples studied with a frequency of 3 students a score of $13-15.32$ or $25 \%$, a frequency of 2 students with a score of 15.33-17.65 or $25 \%$, with a frequency of 3 students with a score of $17.66-19.89$ or $25 \%$, with a frequency of 1 student, with 
a score of $19.90-20.22$ or $14 \%$, with a frequency of 1 student, with a score of $21.23-23.55$ or $14 \%$.

Table 2. Frequency distribution for final test for the ability of students' front kicks in pencak silat extracurricular activities at KH.Ahmad Dahlan Islamic boarding school Teluk Kuantan.

\begin{tabular}{cccc}
\hline No. & Interval & Frequency & Percentage $\%$ \\
\hline 1 & $13-15.32$ & 3 & $25 \%$ \\
2 & $15.33-17.65$ & 2 & $25 \%$ \\
3 & $17.66-19.89$ & 3 & $25 \%$ \\
4 & $19.90-20.22$ & 2 & $14 \%$ \\
5 & $21,23-23.55$ & 2 & $14 \%$ \\
\hline
\end{tabular}

3.2 Testing of Research Hypotheses

Table 3. Data analysis in the pre-test and post-test of the ability

of the front kick students of extracurricular pencak silat at Islamic boarding school KH. Ahmad Dahlan Teluk Kuantan.

\begin{tabular}{|c|c|c|c|c|c|}
\hline $\begin{array}{l}\text { Mean front } \\
\text { kick ability } \\
\text { pree post } \\
\text { test test }\end{array}$ & Df & $\begin{array}{c}\text { Level of } \\
\text { significan } \\
t\end{array}$ & $\begin{array}{c}\mathrm{t} \\
\mathrm{tabl} \\
\mathrm{e}\end{array}$ & $\begin{array}{c}\mathrm{t} \\
\text { arithm } \\
\text { etic }\end{array}$ & $\begin{array}{c}\text { inferenc } \\
\mathrm{e}\end{array}$ \\
\hline $\begin{array}{cl}16.2 & -16.6 \\
5 & 6\end{array}$ & $\begin{array}{l}\mathrm{n}- \\
1= \\
12- \\
1= \\
11\end{array}$ & $5 \%$ & 2,13 & 2,30 & $\begin{array}{c}\text { Signific } \\
\text { ant }\end{array}$ \\
\hline
\end{tabular}

From the results of the research test presented above, the value of $\mathrm{t}$ arithmetic $=2.30$ while $\mathrm{t}$ table $=$ 2.13 with a significant $5 \%$ and $\mathrm{df}=\mathrm{n}-1(12-1)=11$ suggests that: the results of the strength test have an effect on the ability of Student Kick in Pencak Silat Extracurricular Activities at KH. Ahmad Dahlan Islamic Boarding School Islamic Boarding School significantly and it presented in the point that $t$ arithmetic $>\mathrm{t}$ table.

Thus, the provision of strength training can increase the ability of Students' Front Kicks in the Activities of Extracurricular Pencak Silat at Islamic Boarding School KH Ahmad Dahlan Teluk Kuantan.

\section{Discussion}

Based on the data of testing above, it could be prooved that there is a significant influence between the variables $\mathrm{X}$ and $\mathrm{Y}$, namely between strength training affect the ability of the results of the student's front kick in the pencak silat extracurricular activities at KH.Ahmad Dahlan Islamic boarding school Teluk Kuantan. It can be seen from the point of $t$ arithmetic 2.30 can be accepted. The $t$ table of 2.13 shows the value of $t$ arithmetic $>t$ table $(2.30>2.13)$. Thus it can also be stated that the strength training has an influence on the results of the ability of students' front kicks in the extracurricular activities of the pencak silat at
Islamic Boarding School of KH Ahmad Dahlan, Teluk Kuantan.

Based on data analysis, it proves that the results of the variables studied with the number of subjects (12 people) obtained significant boundary numbers at a significant level of 5\% at 2.13 indicating that the results of calculation of the effect of strength training on students' front kick ability in pencak silat extracurricular activities KH.Ahmad Islamic boarding school Dahlan Teluk Kuantan is a $t$ arithmetic $>t$ table (2.30> 2.13). Thus, $\mathrm{t}$ arithemtic $>\mathrm{t}$ table, then Ho is rejected and Ha is accepted.

In sports activities such as front kicks, it is necessary to have strength training. Leg muscle strength training is a training pattern that agrees on leg muscle strength. According to Ariyati (2006) that the power carrying capacity and speed of muscle contraction are dynamic and explosive and it involves spending maximum muscle strength in the fastest time.

Kicking is an attack pattern from the front, the target is the heart of the opponent. According to Lubis (2014) front kick or attack straight kick uses one foot and leg, the trajectory to attack can also be said as a defense or defense in terms of attack techniques, a general attack carried out by athletes is an attack using a kick, therefore kick technique must be truly wellcontrolled.

The magnitude of the effect on the ability of the students' front kicks in the extracurricular activities of the Pencak Silat at Islamic boarding school of $\mathrm{KH}$ Ahmad Dahlan in Teluk Kuantan showed a good results. It means that there was a good influence between the strength training on the ability of the front kick. It is explained the average front kick ability of students in the extracurricular activities in the Pencak Silat at Islamic boarding school of KH Ahmad Dahlan Teluk Kuantan is categorized as good. This indicates that there is a need for intensive strength training so that students' front kick ability in the Islamic boarding school extracurricular activities. KH.Ahmad Dahlan Teluk Kuantan

\section{CONCLUSION AND SUGGESTION}

\section{Conclusion}

Based on the results of data analysis and interpretation of research data, it can be concluded that there is a significant influence between strength training and the ability of students to kick in the extracurricular activities of pencak silat Islamic boarding school KH. Ahmad Dahlan Teluk Kuantan. With To> Tho (2,30> $2,13)$.

\section{Suggestions}

1. Based on the results of the research obtained, some suggestions can be stated as follows: 
2. To students, exercise sports more and more. Because this is their hobbies and talents, because it is impossible for sports to become the next career.

3. To students, continue to be trained in techniques in pencak silat, especially the ability of front kick.

4. To the coach, continue to provide strength training especially strength training of front kick, so that students are more enthusiastic in doing the exercises

5. To the school, to provide more complete sports facilities and infrastructure for developing the talents of students.

\section{REFERENCES}

[1] Arikunto, suharsimi. 2010 Prosedur penelitian suatu pendekatan praktik. Jakarta : Rineka Cipta.

[2] Hendri, Irawadi. 2011. Kondisi Fisik dan Pengukurannya : Fik UNP.

[3] Harsono. 2001. Coaching dan AspekAspek Psikologis Dalam Choching. Jakarta : CV. Tambak Kusuma.

[4] Ismaryati. 2006. Tes dan Pengukuran Olahraga. Surakarta : UNS Press.

[5] Lubis, Johansyah 2014.Pencak Silat Edisi Ke Dua. Jakarta : PT RajaGrafindo Persada.

[6] Lubis, Johansyah 2016.Pencak Silat Edisi Ke Tiga. Jakarta : PT RajaGrafindo Persada.

[7] Mulyanda 2013. Pendidikan Pencak Silat. Bandung : PT Remaja Rosda karya.

[8] Erwin Setyo Kriswanto 2015. Pencak Silat, Yogyakarta : PT PustakaBaru.

[9] Rahmani, Mikada 2014. Buku Super Lengkap Olahraga. Jakarta Dunia Cerdas.

[10] Sugiono. 2010. Metedologi Penelitian. Jakarta : Asdi Mahastya.

[11] Suherman, Adang Dkk 2007. Pedekatan permainan dan kompetisi, Jakarta : Rineka Cipta.

[12] Syafruddin. 2011. Ilmu Kepelatihan Olahraga. Padang : UNP. UU. Keolahragaan Nasional UU RI. No. 3 Th. 2005. Jakarta : Sinar Grafika. 